\title{
DEMOGRAPHIC FACTORS AND JOB SATISFACTION OF MALAYSIAN CHINESE INDEPENDENT SCHOOL TEACHERS
}

\author{
Christina Ong Sook Beng ${ }^{1 *}$, Siah Poh Chua ${ }^{2}$ and Tan Swee Mee ${ }^{1}$ \\ ${ }^{1}$ Department of Languages and Linguistics, Universiti Tunku Abdul Rahman, \\ Jalan Universiti, Bandar Barat, 31900 Kampar, Perak, Malaysia \\ ${ }^{2}$ Department of Psychology and Counselling, Universiti Tunku Abdul Rahman, \\ Jalan Universiti, Bandar Barat, 31900 Kampar, Perak, Malaysia \\ *Corresponding author: ongsb@utar.edu.my
}

Publication date: 30 June 2020

To cite this article: Christina Ong Sook Beng, Siah Poh Chua, \& Tan Swee Mee. (2020). Demographic factors and job satisfaction of Malaysian Chinese independent school teachers. Asia Pacific Journal of Educators and Education, 35(1), 137-156. https://doi. org/10.21315/apjee2020.35.1.8

To link to this article: https://doi.org/10.21315/apjee2020.35.1.8

\begin{abstract}
The aims of this study are to identify the dimension of job satisfaction among Chinese independent school teachers and to explore the association between demographic factors and their job satisfaction. Purposive sampling was used to recruit 121 teachers from five Chinese independent schools. They were requested to fill out demographic information and a job satisfaction survey. Findings showed that job interest and working environment are the main dimension of job satisfaction that Chinese independent school teachers are satisfied with. It was found that years of teaching is positively associated with job satisfaction, whereas income is negatively associated with job satisfaction. Further analysis suggested that: (i) those with administrative position and with more years of teaching experience are positively associated with job satisfaction in terms of reward; (ii) higher income is negatively associated with working environment, salary and benefits and workload; (iii) age is positively associated with workload and interest in job. This study implied that better monetary compensation and salary scheme should be drafted to enhance Chinese independent school teachers' job satisfaction.
\end{abstract}

Keywords: Job satisfaction, demographic factors, teachers, Malaysian Chinese independent schools

(C) Penerbit Universiti Sains Malaysia, 2020. This work is licensed under the terms of the Creative Commons Attribution (CC BY) (http://creativecommons.org/licenses/by/4.0/). 


\section{INTRODUCTION}

Job satisfaction is defined by Spector (1997) as the degree to which working adults like their jobs. Evans (1997) detailed the definition by asserting the importance of satisfying individuals' needs in relation to their jobs. Focusing on job satisfaction among teachers, it is referred to as a general measure to predict effective schools (Zigarreli, 1996) and the degree to which teacher is satisfied with the job conditions (Evans, 1997). It is important to identify the characteristics of teachers with high and low level of job satisfaction. Doing so could predict which teachers are satisfied with their job (Bogler, 2002), ultimately improving the teaching and learning activities as well as operation of the schools. Teachers themselves are supposed to be motivated before they can educate and nurture their students. According to Bogler (2002), high job satisfaction means they are highly committed in teaching which will benefit the school in general by not only producing high-achievers but also favouring organisational development. In short, a successful education system that can produce high-achievers does not only depend on qualified teachers but also satisfied teachers.

It is imperative to find out factors that are relevant to teachers' job satisfaction, especially among Chinese independent school teachers. To the best of the researchers' knowledge, no empirical study has been conducted to identify factors associating with teachers' job satisfaction in Chinese independent schools. Chinese independent school is a type of private school in Malaysia which offers secondary education in the Chinese language. It is a result of the enactment of Education Act 1961 aiming to change the medium of instruction of all schools from English to bahasa Melayu. Some Chinese secondary schools (i.e. Chinese independent schools today) opted to not adhere to the act by persisting in providing Chinese education. This is because an organisation named the United Chinese School Committees' Association of Malaysia (also known as Dong Zong) has been working relentlessly with the United Chinese School Teachers' Association of Malaysia (commonly known as Jiao Zong) since 1954 to defend and develop mother-tongue education for the Chinese community in Malaysia (United Chinese School Committees' Association of Malaysia, 2019). However, they are not accountable to any policies and rules set by Malaysia Ministry of Education (Gill, 2013) which means, every Chinese independent school is given the freedom to make its own decisions.

Even though Chinese independent schools are not sanctioned by Malaysian government (Chong \& Norsimah, 2007) and the Unified Examination Certificate (UEC) administered by Dong Jiao Zong is not listed as a requirement to enter public universities in Malaysia (Gill, 2013; United Chinese School Committees' Association of Malaysia, 2019), the UEC is recognised by more than 400 higher 
institutions worldwide (Lee \& Leeves, 2015). Despite the denial of UEC by Malaysian public universities, a $37 \%$ increase in the total student population from 53,258 students in 2000 to 84,462 students in 2018 in 60 schools was observed alongside 4,857 teachers (United Chinese School Committees' Association of Malaysia, 2019). The significant increase in the number of students enrolling in Chinese independent schools nationwide, recording an upsurge of $35 \%$ within a decade (Siah, Ong, Tan, Sim, \& Thoo, 2018) shows a preference towards this type of school especially among the Chinese community.

As indicated by Gil-Flores (2017), factors affecting teachers' job satisfaction can be divided into internal (i.e. school operations) and external (i.e. social context and educational policies); this study focuses on internal factors, especially the demographic factors, that are associated with job satisfaction among Chinese independent school teachers. Although there are many studies exploring the relationships between demographic factors and job satisfaction among teachers in different school system around the world, their results vary widely. Due to differing culture and context (McCarthy et al., 2017), it is unlikely that findings from past studies are applicable to teachers in Chinese independent schools. Thus, based on the findings of this study, suggestions can be given to the managements of Chinese independent schools to draft policies aiming to not only enhance their teachers' job satisfaction but also to retain them and lead them to be more productive and committed to their schools.

\section{OVERVIEW OF CHINESE INDEPENDENT SCHOOLS IN MALAYSIA}

As Chinese independent schools are not part of Malaysia public school system, their curriculum and objectives are different from national schools. One of the main differences between Chinese independent schools and national schools is that the former prioritises Chinese culture which means the syllabi in relevant subjects such as History are skewed towards promotion and preservation of Chinese values and cultural legacy (United Chinese School Association Committees' of Malaysia, 2019). This is proven when students in Chinese independent schools are required to study the teachings of Confucius, Chinese literature, Chinese calligraphy, and Four Books and Five Classics which are closely monitored and standardised by Dong Jiao Zong (Gill, 2013). Secondly, certain Chinese independent schools give an option for their students to take Malaysian national examinations alongside the UEC while certain schools made it compulsory for their students to sit for both types of examination (Lee \& Leeves, 2015). Thirdly, the medium of instruction for all subjects is Chinese except language-based subjects because it is consistent 
with advocation of mother tongue education which is spelt out by Dong Jiao Zong. Fourthly, the celebrations of various Chinese festivals besides Chinese New Year such as Chap Goh Meh, Qingming Festival are prioritised to the extent that the school authority would apply special holidays from Malaysia Ministry of Education. Lastly, students in Chinese independent schools are required to sit and pass UEC and Senior Unified Examination Certificate (SUEC) which are overseen by Dong Jiao Zong (United Chinese School Association Committees' of Malaysia, 2019).

Compared to national secondary schools, an obvious preference towards Chinese independent schools was mentioned by Lee and Leeves (2015). Similarly, Low (2015) and Siah et al.'s (2018) studies also indicated that Chinese independent schools are favoured these days. The former investigated the perception of students for their decision to study in Chinese independent schools while the latter studies explored factors affecting parents' school choice. Although both studies gathered responses from two different groups of respondents - students and parents, the findings were similar where highly committed teachers and opportunities to be connected with Chinese language, value and cultures were the main reasons for the choice of Chinese independent schools over national schools (Low, 2015; Siah et al. 2018).

According to the reports on teacher resources in Chinese independent schools, the qualification of teachers varies from degree to diploma obtained from Malaysia, China, Taiwan, Hong Kong/Macau, Singapore, United Kingdom, Australia, New Zealand and United States of America (United Chinese School Association Committees' of Malaysia, 2019). Having such a complicated constitution of teacher resources in Chinese independent schools, the backgrounds of these teachers may affect their job satisfaction in one way or another. They may encounter many challenges such as professionalism, teaching expectation, classroom management and teacher-student interactions. As the fort defender of mother tongue education in Malaysia, Dong Jiao Zong, together with the cooperation from the New Era College, they provide a diploma programme in education to teachers who do not have any teacher training in the Chinese independent school. One of the researchers in the present study has been acting as an on-site supervisor of the course since 2013. Besides observing classes conducted by teacher trainees' and assessing their professional training, the supervisor also offers counselling sessions to these trainees.

Having observed the learning environment in Chinese independent schools and complicated constitution of teacher resources in these schools, teachers may not 
be satisfied because they seem to bear more responsibilities to meet the objectives of the school, students' and parents' expectation.

\section{Factors Influencing Teachers' Job Satisfaction}

Similar to other workers, teachers' job satisfaction is influenced by demographic factors such as age, gender, income, education qualification, marital status and total years of working experience. Past studies discussing the effects of the aforementioned factor on teachers' job satisfaction in schools abroad and Malaysia are reviewed in the following paragraphs. Prior to that, an overview of variables correlating with job satisfaction is described.

As mentioned earlier, factors affecting teachers' job satisfaction can be separated into two; namely internal and external (Gil-Flores, 2017). Because only the former is relevant to this study, factors such as management's role, workload, reward, relationship with colleagues are addressed while the latter is disregarded. Most teachers were found to be satisfied when they have good relationship with their colleagues (Kadtong, Unos, Antok, \& Midzid, 2017; Mafuzah \& Juraifa, 2016; Muhammad Madi, Uli, \& Parasuraman, 2009; Skaalvik \& Skaalvik, 2009; Zainudin, Junaidah, \& Nazmi, 2010). Moreover, Hoque, Ahmad Zabidi and Zohora (2012) asserted that when cooperative and supportive management style is adopted by school principals, teachers feel more comfortable. Getting rewards for the work done in the form of recognition (Fatima \& Ali, 2016; Fernet, Trepanier, Austin, \& Levesque-Cote, 2016; Zarisfizadeh, 2012) and promotional opportunities (Santhapparaj \& Syed, 2005; Zainudin et al., 2010) are found to be related to teaching staff's satisfaction. Heavy workload has been identified as one of the main causes of job dissatisfaction among teachers in Malaysia (Muhammad Madi et al., 2009; Zarisfizadeh, 2012) and abroad (Lam \& Yan, 2011 - Hong Kong; Fernet et al., 2016 - Canada; Skaalvik \& Skaalvik, 2009 - Norway; Tafida, Clement, \& Raihan, 2015 - Nigeria). Lam and Yan (2011) added that non-teaching workload gives teachers little satisfaction. Factors contributing to teachers' satisfaction such as maintaining a good relationship with co-workers and superiors, receiving rewards, and wanting less workload attested above correspond to the Maslow's Hierarchy of Needs. It shows that, teachers are normal human beings who would want to feel belonged, accomplished and well-rested which are the basic and psychological needs proposed by Maslow (1943).

Past literature has shown the possibility of teachers' demographic factors in predicting their job satisfaction. The most widely discussed factor is teachers' income. Receiving salary that does not reflect the job demand is a common issue in the academic world. Undoubtedly, teachers are more satisfied when they receive 
high income (Fatima \& Ali, 2016; Lam \& Yan, 2011; Muhammad Madi et al., 2009; Zainudin et al., 2010). However, there are evidences indicating other reasons besides income that contribute to teachers' satisfaction. For example, wanting to work with young people (Sharma \& Jyoti, 2006) and nature of job (Koustelios, 2001). This is supported by Bogler (2002) who reiterated the point on those who do not view their teaching job as a profession are dissatisfied. Gender is another significant predictor of teacher job satisfaction and generally researchers agreed that females are more satisfied with this profession (Bogler, 2002; Gil-Flores, 2017; Koustelios, 2001) except Muhammad Madi et al. (2009), whose respondents were secondary school teachers from Sabah, a region in East Malaysia, reported that male teachers are more satisfied. With regard to age, some found that an increase in age leads to a slight decline in job satisfaction (Gil-Flores, 2017). Other researchers found younger teachers are more dissatisfied and are prone to changing careers (Ingersoll, 2001; Sargent \& Hannum, 2005). In other words, younger teachers are more career-driven, more hungry for knowledge and experience, more open to learning new things while the working performance among older teachers may become mediocre with each passing year, probably because they have got used to the routine, with their enthusiasm and passion for discovery getting dulled over time. Finally, teachers with longer years of teaching experience are found to be more satisfied (Muhammad Madi et al., 2009) but Skaalvik and Skaalvik (2009, p. 522) discovered that "years of experience as a teacher was weakly, but negatively related to job satisfaction." It appears that there are two sides of the same coin when teacher's demographic factors namely salary, gender, age and experience duration are taken into consideration as predictors of their job satisfaction. The contradicting findings may be contributed by teacher variables or external factors, nevertheless, as mentioned by Gil-Flores (2017), the former is more significant in predicting teacher job satisfaction. Whether or not the effect that teachers with different demographic factors has on their job satisfaction as highlighted in past studies are similar to Malaysian Chinese independent school teachers will be investigated in this study.

\section{AIMS OF THE STUDY}

As mentioned by Bogler (2002), Gil-Flores (2017) and Koustelios (2001), teachers' demographic factors do affect job satisfaction, but most of these studies were conducted in the western countries. The extent to which findings of studies conducted in the western countries are applicable to Malaysian teachers have yet been researched, especially among teachers at Chinese independent schools and not many empirical studies have been conducted. Similar to Bogler (2002), this study hopes to offer insights to principals and stakeholders of Chinese independent 
schools specifically the board of governor to compare and contrast teacher job satisfaction relative to their demographic variables to grasp the difference in teacher quality. Another equally important rationale for conducting this study is that past researchers such as Hoque et al. (2012) and Muhammad Madi et al. (2009) have been more interested in Malaysian national secondary school teachers which are undeniably larger in size as compared to the teaching force in the former type of school. It is crucial to focus on the situation in Chinese independent schools. As stated earlier, there are more parents who prefer sending their children to study in Chinese independent schools nowadays (Siah et al., 2018). This is in line with higher enrolment in private schools following the rise in the average household income level as indicated in Malaysian Education Blueprint 2013-2025. The number of students in private schools including Chinese independent schools is expected to steadily increase in the years to come based on the current statistics alongside the number of teachers. Teachers' satisfaction in this type of school will definitely be affected. Therefore, this study aims to answer the following research questions:

1. Which dimensions of job satisfaction that Chinese independent school teachers are more satisfied with?

2. Which demographic factors (i.e. age, gender, highest education, marital status, administrative position, income, total years of teaching in the school, and total years of teaching) are significant predictors of Chinese independent school teachers' job satisfaction?

\section{METHOD}

\section{Participants}

Using purposive sampling, a total of 150 teachers from five Chinese independent schools in one of the northern states in Malaysia, Perak were recruited for the survey in this study. As sampling frames of teachers could not be obtained from the schools, purposive sampling was used to recruit participants. Purposive sampling is a non-probability sampling technique used to sample a target population with certain characteristics relevant to the research (Etikan, Musa, \& Alkassim, 2016). The criteria of purposive sampling in this study would be that the samples of the study must be a teacher at Chinese independent schools. A total of 121 valid questionnaires were collected, which means the response rate is $80.67 \%$. Most of them were Chinese $(81 \%)$, have a degree or master degree $(76.9 \%)$, not involved in administrative task (60.3\%), aged below 40 years old (66.9\%), have less than five 
years of teaching experience (55.4\%), females (53.7\%) and single (51.2\%). Table 1 shows the demographic background of the participants of this study.

Table 1. Demographic background of teachers from Chinese independent schools $(n=121)$

\begin{tabular}{|c|c|c|}
\hline Demography & & Percentage $(\%)$ \\
\hline \multirow[t]{2}{*}{ Age } & Below 40 & 66.9 \\
\hline & Above 40 & 33.1 \\
\hline \multirow[t]{2}{*}{ Gender } & Male & 46.3 \\
\hline & Female & 53.7 \\
\hline \multirow[t]{2}{*}{ Marital status } & Married & 48.8 \\
\hline & Single & 51.2 \\
\hline \multirow[t]{2}{*}{ Ethnicity } & Chinese & 81.0 \\
\hline & Others & 19.0 \\
\hline \multirow[t]{2}{*}{ Monthly income } & Above RM2000 & 65.3 \\
\hline & Equal or below RM2000 & 34.7 \\
\hline \multirow[t]{2}{*}{ Highest education obtained } & Degree and above & 76.9 \\
\hline & Certificate & 23.1 \\
\hline \multirow[t]{2}{*}{ Involvement in administrative work } & Yes & 39.6 \\
\hline & No & 60.4 \\
\hline \multirow[t]{4}{*}{ Teaching experience (in current school) } & $1-2$ years & 49.6 \\
\hline & $3-5$ years & 19.8 \\
\hline & $6-10$ years & 10.7 \\
\hline & 10 years and above & 19.8 \\
\hline \multirow[t]{4}{*}{ Total years of teaching } & $1-2$ years & 34.7 \\
\hline & $3-5$ years & 22.3 \\
\hline & $6-10$ years & 12.4 \\
\hline & 10 years and above & 30.6 \\
\hline
\end{tabular}

\section{Instrument}

The questionnaire was made up of two main sections: (a) demographic background and; (b) the job satisfaction survey (JSS). 


\section{Demographic background}

Participants need to fill in their demographic background such as monthly income, marital status, age and education level.

\section{Job satisfaction survey (JSS)}

This questionnaire includes 36 items and 19 items are negatively worded items. Participants were asked to respond to the JSS using a Likert type scale of 1 to 6 . One (1) represents a value which was 'strongly disagree' and six (6) represents 'strongly agree'. There are nine subscales in JSS: Pay, promotion, supervision, fringe benefits, contingent rewards, operating conditions, coworkers, nature of work and communication. There are four items in each subscale. In Spector's work (1985), the nine subscales correlated moderately among each other, the internal consistency is ranged from 0.60 to 0.91 (as cited in Spector, 1997). However, the results of parallel analysis proposed a five factor structure, thus, an exploratory factor analysis with Varimax rotation was then run to extract five factors that explained $48.85 \%$ of total variance, $\mathrm{KMO}=0.76$, Bartlett's Test of Sphericity $=1873.82$, $p<0.001$ (see Table 2). Nine items were removed due to low factor loadings $(<0.40)$ or cross-loading with other items (Osborne \& Costello, 2009).

Table 2. Results of factor analysis for factors influencing teachers' job satisfaction

\begin{tabular}{lccccc}
\hline & \multicolumn{5}{c}{ Factors } \\
\cline { 2 - 6 } & $\begin{array}{l}\text { Working } \\
\text { environment }\end{array}$ & $\begin{array}{c}\text { Salary } \\
\text { and } \\
\text { benefit }\end{array}$ & Workload & $\begin{array}{c}\text { Interest } \\
\text { in job }\end{array}$ & Reward \\
\hline $\begin{array}{l}\text { Q3. My supervisor is quite } \\
\text { competent in doing his/her job. }\end{array}$ & $\mathbf{. 7 4 2}$ & .281 & .185 & .118 & -.013 \\
$\begin{array}{l}\text { Q30. I like my supervisor. } \\
\begin{array}{l}\text { Q11. Those who do well on the } \\
\text { job stand a fair chance of being } \\
\text { promoted. }\end{array}\end{array}$ & $\mathbf{. 7 2 2}$ & .165 & .215 & .241 & -.026 \\
$\begin{array}{l}\text { Q21. My supervisor shows too } \\
\text { little interest in the feelings of } \\
\text { subordinates. }\end{array}$ & $\mathbf{. 6 5 2}$ & .098 & .190 & -.116 & -.054 \\
$\begin{array}{l}\text { Q12. My supervisor is unfair } \\
\text { to me. }\end{array}$ & $\mathbf{. 6 2 7}$ & .251 & -.080 & .027 & .114 \\
$\begin{array}{l}\text { Q33. I am satisfied with my } \\
\text { chances for promotion. }\end{array}$ & $\mathbf{. 6 2 6}$ & .241 & -.089 & .198 & .013 \\
\hline
\end{tabular}


Table 2. (continued)

\begin{tabular}{|c|c|c|c|c|c|}
\hline & \multicolumn{5}{|c|}{ Factors } \\
\hline & $\begin{array}{l}\text { Working } \\
\text { environment }\end{array}$ & $\begin{array}{l}\text { Salary } \\
\text { and } \\
\text { benefit }\end{array}$ & Workload & $\begin{array}{l}\text { Interest } \\
\text { in job }\end{array}$ & Reward \\
\hline $\begin{array}{l}\text { Q18. The goals of this } \\
\text { organisation are not clear to } \\
\text { me. }\end{array}$ & .625 & .114 & -.132 & .298 & -.075 \\
\hline $\begin{array}{l}\text { Q14. I do not feel that the work } \\
\text { I do is appreciated. }\end{array}$ & .597 & .239 & .202 & .050 & -.233 \\
\hline $\begin{array}{l}\text { Q34. There is too much } \\
\text { bickering and fighting at work. }\end{array}$ & .478 & .235 & .226 & -.103 & -.028 \\
\hline $\begin{array}{l}\text { Q36. Work assignments are not } \\
\text { fully explained. }\end{array}$ & .477 & .261 & .298 & .000 & -.076 \\
\hline $\begin{array}{l}\text { Q26. I often feel that I do not } \\
\text { know what is going on with the } \\
\text { organisation. }\end{array}$ & .470 & -.080 & .092 & .347 & -.101 \\
\hline $\begin{array}{l}\text { Q9. Communications seem } \\
\text { good within this organisation. }\end{array}$ & .452 & .079 & .300 & .095 & .111 \\
\hline Q25. I enjoy my co-workers. & .403 & .006 & .347 & .280 & .178 \\
\hline $\begin{array}{l}\text { Q28. I feel satisfied with my } \\
\text { chances for salary increases. }\end{array}$ & .284 & .716 & .019 & .030 & .085 \\
\hline $\begin{array}{l}\text { Q32. I don't feel my efforts are } \\
\text { rewarded the way they should } \\
\text { be. }\end{array}$ & .340 & .678 & .257 & -.138 & .262 \\
\hline $\begin{array}{l}\text { Q10. Raises are too few and far } \\
\text { between. }\end{array}$ & -.174 & .605 & .065 & .231 & -.313 \\
\hline $\begin{array}{l}\text { Q29. There are benefits we } \\
\text { do not have which we should } \\
\text { have. }\end{array}$ & .270 & .578 & -.018 & .066 & .130 \\
\hline $\begin{array}{l}\text { Q1. I feel I am being paid a fair } \\
\text { amount for the work I do. }\end{array}$ & .229 & .521 & .342 & -.024 & .089 \\
\hline $\begin{array}{l}\text { Q13. The benefits we receive } \\
\text { are as good as most other } \\
\text { organisations offer. }\end{array}$ & .162 & .509 & .389 & .016 & -.131 \\
\hline $\begin{array}{l}\text { Q5. When I do a good job, I } \\
\text { receive the recognition for it } \\
\text { that I should receive. }\end{array}$ & .364 & .495 & .017 & .070 & -.285 \\
\hline $\begin{array}{l}\text { Q31. I have too much } \\
\text { paperwork. }\end{array}$ & .056 & .146 & .759 & .102 & -.003 \\
\hline
\end{tabular}


Table 2. (continued)

\begin{tabular}{lccccc}
\hline & \multicolumn{5}{c}{ Factors } \\
\cline { 2 - 6 } & $\begin{array}{l}\text { Working } \\
\text { environment }\end{array}$ & $\begin{array}{c}\text { Salary } \\
\text { and } \\
\text { benefit }\end{array}$ & Workload & $\begin{array}{c}\text { Interest } \\
\text { in job }\end{array}$ & Reward \\
\hline $\begin{array}{l}\text { Q24. I have too much to do at } \\
\text { work. }\end{array}$ & .089 & .274 &. $\mathbf{6 5 5}$ & .160 & -.058 \\
$\begin{array}{l}\text { Q35. My job is enjoyable. } \\
\text { Q8. I sometimes feel my job is }\end{array}$ & .079 & -.007 & .166 & $\mathbf{. 7 4 0}$ & .172 \\
meaningless. & .160 & .132 & -.039 & $\mathbf{. 7 2 5}$ & -.136 \\
$\begin{array}{l}\text { Q17. I like doing the things I } \\
\text { do at work. }\end{array}$ & .145 & -.031 & .216 & $\mathbf{. 6 4 9}$ & .073 \\
$\begin{array}{l}\text { Q27. I feel a sense of pride in } \\
\text { doing my job. }\end{array}$ & .147 & -.045 & -.203 & $\mathbf{. 6 3 0}$ & -.072 \\
$\begin{array}{l}\text { Q6. Many of our rules and } \\
\text { procedures make doing a good } \\
\text { job difficult. }\end{array}$ & -.183 & .232 & .153 & $\mathbf{. 4 7 6}$ & .147 \\
$\begin{array}{l}\text { Q23. There are few rewards for } \\
\text { those who work here. }\end{array}$ & .069 & .191 & -.014 & .171 & $\mathbf{. 6 8 0}$ \\
$\begin{array}{l}\text { Q15. My efforts to do a good } \\
\text { job are seldom blocked by red } \\
\text { tape. }\end{array}$ & .066 & -.106 & -.045 & .251 & $\mathbf{. 6 2 7}$ \\
\end{tabular}

\section{FINDINGS}

\section{Correlation among the Five Factors}

By using Pearson correlation analysis (Table 3), the results showed that working environment is positively correlated with salary and benefit, workload and interest in job, $p<0.01$, but it is not scientifically correlated with reward. Reward is positively correlated with interest in job, $p=0.013$.

\section{Job Satisfaction}

Among the five factors, the highest satisfactory factor found in this survey is interest in job $(\mathrm{M}=4.29, \mathrm{SD}=.76)$, followed by working environment 
$(\mathrm{M}=4.09, \mathrm{SD}=.77)$, reward $(\mathrm{M}=3.71, \mathrm{SD}=.97)$, pay and benefit $(\mathrm{M}=3.23$, $\mathrm{SD}=.82)$, and workload $(\mathrm{M}=2.77, \mathrm{SD}=1.07)$.

Table 3. Correlation coefficients among the five factors of job satisfaction $(n=121)$

\begin{tabular}{lccccccc}
\hline & $\mathrm{M}$ & $\mathrm{SD}$ & 1 & 2 & 3 & 4 & 5 \\
\hline Working environment & 4.09 & .77 & 1 & $.59^{* * *}$ & $.36^{* * *}$ & $.28^{* *}$ & .11 \\
Salary and benefit & 3.23 & .82 & $.59^{* * *}$ & 1 & $.41^{* * *}$ & .16 & .11 \\
Workload & 2.76 & 1.07 & $.36^{* * *}$ & $.41^{* * *}$ & 1 & .18 & .02 \\
Interest in job & 4.29 & .76 & $.28^{* *}$ & .16 & .18 & 1 & $.23^{* *}$ \\
Reward & 3.71 & .97 & .11 & .11 & .02 & $.23^{*}$ & 1 \\
\hline
\end{tabular}

Notes: $* p<.05 ; * * p<.01 ; * * * p<.001$

\section{JSS and Teachers' Demographic Background}

A multiple regression analysis with stepwise method was run to identify the demographic background that are significantly related to JSS. The demographic background included were age, gender, highest education (certificate vs. degree or above), marital status (married vs. single), administrative position (yes vs. no), income (above RM2000 vs. equal or below RM2000), total years of teaching in the school and total years of teaching. The regression was found to be significant, $\mathrm{F}(2,117)=5.89, p=.004$. It explained $9.2 \%$ of total variance. Two demographic factors, i.e. income $(B=-.33, t=-3.11, p=.002)$ and total years of teaching ( $B=0.09, t=2.39, p=0.019)$, were found to be significant predictors of JSS. A further analysis was conducted by using the similar predictors for the five job satisfaction factors separately. Results showed that teachers' age is positively associated with interest in job, while income is negatively associated with work environment, pay and benefits, and workload. Teachers' total years of teaching experience and their involvement in administrative tasks are associated with reward (see Table 4). 
Job Satisfaction of Chinese School Teacher

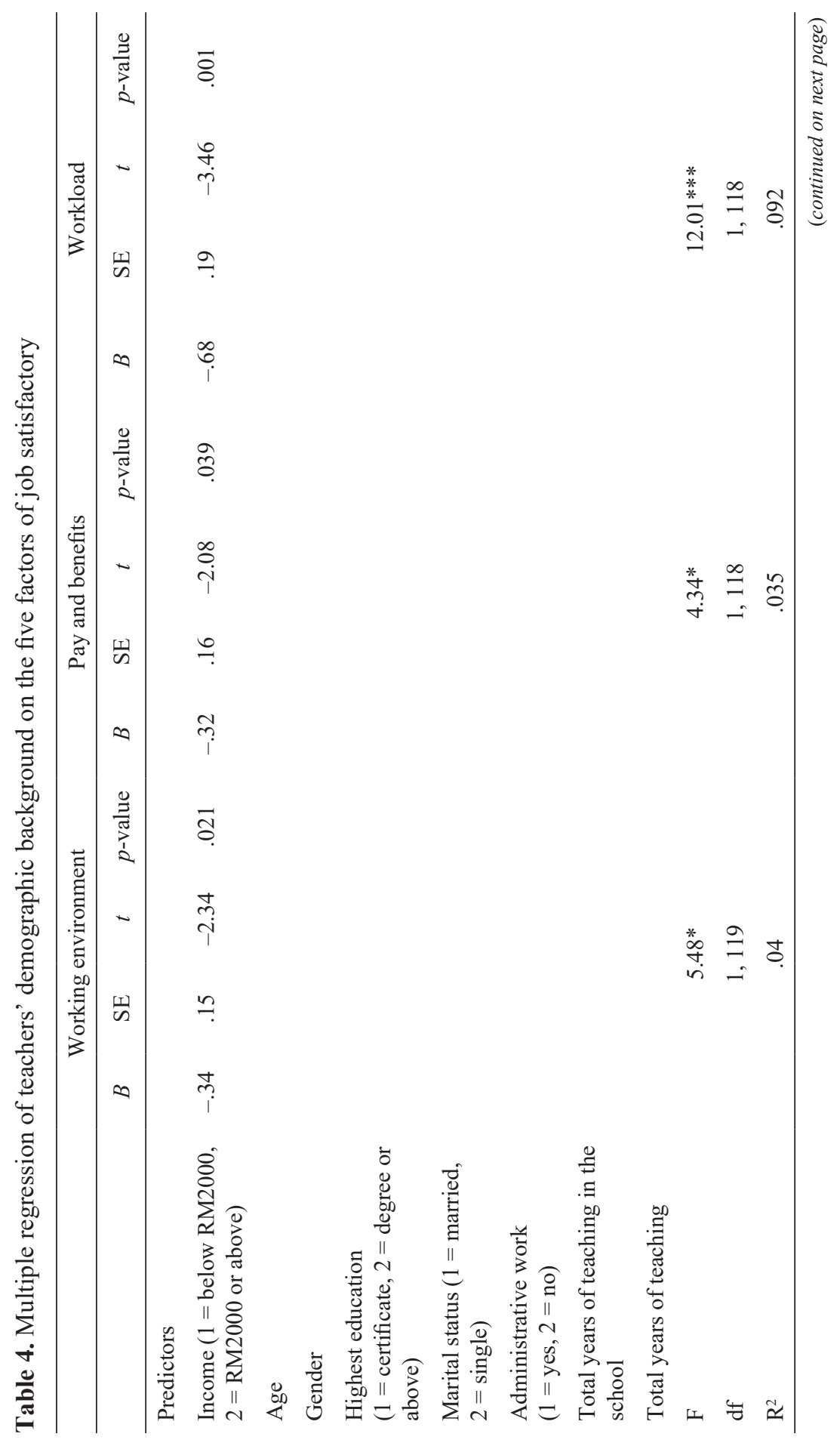


Christina Ong Sook Beng et al.

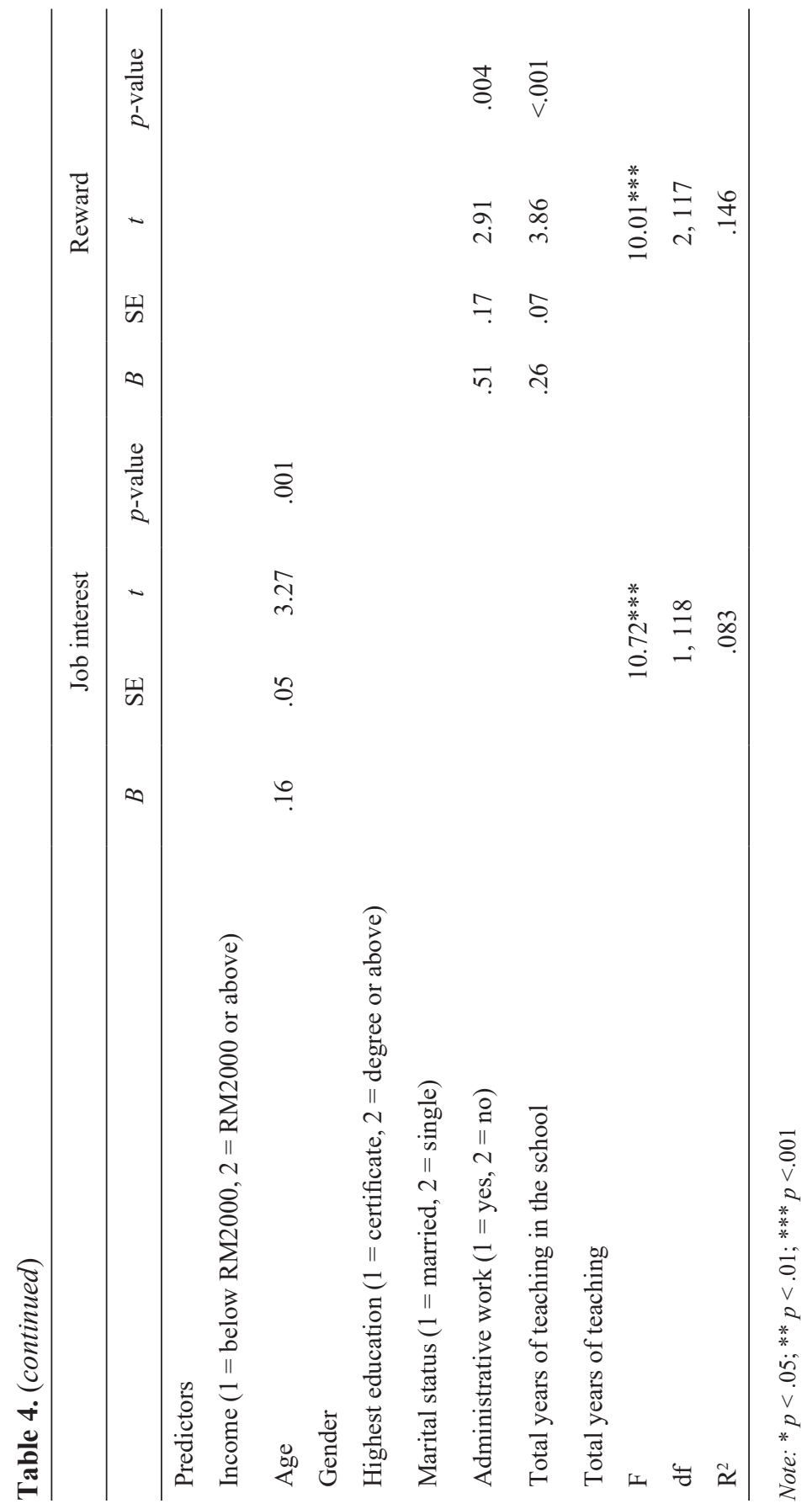




\section{DISCUSSION}

Most studies investigating the relationships between demographic factors and job satisfaction among teachers were carried out in western countries, whether or not those findings are applicable to Malaysian teachers is uncertain. Even when such studies were conducted in Malaysia, past researchers focused on teachers from national schools. There were relatively few job satisfaction studies done among Chinese independent school teachers. Therefore, this study targets at the relationships between demographic factors and job satisfaction among Chinese independent school teachers. Identifying factors influencing Chinese independent school teachers' job satisfaction based on their personal characteristics is crucial. The board of governors, principals, and other stakeholders of Chinese independent schools alongside their teachers can suggest suitable actions to be taken to enhance the teachers' job satisfaction by grouping them according to their personal characteristics. Doing so may encourage teachers to perform their best, eventually producing more well-rounded students.

Findings showed that interest in job and working environment are the main dimension of job satisfaction that Chinese independent school teachers are satisfied with. It can be inferred that Sharma and Jyoti's (2006) claim about teachers choosing to teach because they want to work with young people is true in this context. Working environment was rated as the second source of job satisfaction in this study and it can be linked to the presence of supportive colleagues and principals. This is consistent with research conducted by Kadtong et al. (2017), Mafuzah and Juraifa (2016), Muhammad Madi et al. (2009), Hoque et al. (2012), Skaalvik and Skaalvik (2009), and Zainudin et al. (2010). Workload was rated as the last dimension of job satisfaction in this study and it corresponded with results of past studies (Muhammad Madi et al., 2009; Zarisfizadeh, 2012; Lam \& Yan, 2011; Fernet et al., 2016; Skaalvik \& Skaalvik, 2009; Tafida et al., 2015). As the types of schools between these studies and current studies are different, future studies should be conducted to find out the causes of heavy workload among teachers in Chinese independent schools. The management of the schools should also look into these issues and propose ways to either lessen or ease their heavy workload so that the job satisfaction among the teachers can be sustained.

Focusing on the impact of teachers' demographic factors on their general job satisfaction, results showed years of teaching is positively associated with job satisfaction, whereas income is negatively associated with job satisfaction. The first predictor is not surprising as teacher with more years of teaching are prone to familiarising themselves to the job demands of the schools, thus, they are more likely to be satisfied with their jobs. Higher income was found to be related to 
administrative positions. Teachers holding administrative positions are expected to manage higher workload. This could be the reason for a negative association between income and job satisfaction emerging in the results.

Further analyses of demographic factors on job satisfaction indicated three prominent predictions. Firstly, those with administrative position and with more years of teaching experience are positively associated with job satisfaction in terms of reward. In other words, teachers with longer years of teaching experience and with administrative positions are more satisfied with their job rewards. This result corresponds to Koustelios' (2001, p. 356) study where "as working experience increases, satisfaction with promotion increases."

Secondly, higher income is negatively associated with three dimensions of job satisfactory: working environment, salary and benefits and workload. That means Lam and Yan's (2011) claim about non-teaching workload (also known as administrative task) causes teacher to be dissatisfied is acceptable to a certain extent. It also corresponds to Fatima and Ali (2016) and Muhammad Madi et al. (2009) studies because teachers are reported to be happier when they receive high income for less amount of work done. As teachers who have been receiving higher incomes are those with administrative positions, their low satisfaction with working environment, salary and benefits and workload is alarming because they are the ones holding administrative positions and possessing longer working and teaching experience. Their low job satisfaction in these three dimensions may further affect the management of the schools and other teachers' job satisfaction. It is worth noting that salary and fringe benefits are always highlighted as one of the problems with Malaysian Chinese education (Lee, 2007), thus, it is unsurprising to find teachers in Chinese independent schools managing heavy workload but receiving relatively low income.

Thirdly, age is positively associated with workload and interest in job. This contradicts with Gil-Flores' (2017) finding where age is negatively associated with job satisfaction among Spanish teachers. This could be due to the increase familiarity of their job scope that leads them to become more interested. As the teachers grow older, they may seek for stability in life unlike younger teachers who may still be in the quest of looking for the right job. In other words, Ingersoll (2001) and Sargent and Hannum's (2005) claim about younger teachers job hopping is reasonable. 


\section{CONCLUSION}

Despite the small sample size due to low number of teachers who are only based in the state of Perak, demographic factors contributing to job satisfaction among Chinese independent school teachers in Malaysia have been determined. To reiterate the findings of this study, interest in job and working environment are the two main contributing factors towards Chinese independent school teachers' general job satisfaction while salary is the last. When teachers' demographic factors are taken into consideration to determine their different dimensions of job satisfactions, results showed that teachers' age is positively associated with two different dimensions of job satisfaction namely workload and interest in job. Their income is negatively associated with more dimensions of job satisfaction, which include working environment, salary and benefits and workload, while their working experience and involvement in administrative tasks are associated with reward.

Though income is the least important factor related to overall job satisfaction among Chinese independent school teachers, it should be given attention to. This is because it is negatively associated with many dimensions of job satisfaction, and it involves teachers with administrative positions and with more years of teaching. Their low job satisfaction may affect the management of the schools and the school culture. Therefore, findings of this study imply that the monetary compensation and salary scheme of Chinese independent school teachers must be looked into. If monetary compensation cannot be provided, the school management need to identify other ways of rationalising heavy workload distributing to the teachers. It is also recommended to adopt Farah Shazlin, Muhammad Ridzuan, Nor Maslia, Nurhafizah, and Siti Norashikin's (2018) work-life balance policies i.e. flexibility policies, welfare policies, job design and leave provisions which were drafted after investigating job satisfaction among teachers teaching various subjects in Malaysian boarding schools.

To conclude, Malaysian Chinese independent school teachers' welfare must be prioritised because most of them are presumed to be neglecting the importance of work-life balance; as shown in the findings of this study where workload is the last contributing job satisfaction factor. Finally, a higher salary with better benefits should be provided to these teachers so that they will continue becoming teachers at Malaysian Chinese independent schools, show willingness to take more significant roles in the schools and pursue further studies to improve their professional competency. 


\section{ACKNOWLEDGEMENTS}

This research is funded by Universiti Tunku Abdul Rahman Research Fund (UTARF), 6200/C54.

\section{REFERENCES}

Bogler, R. (2002). Two profiles of school teachers: A discriminant analysis of job satisfaction. Teaching and Teacher Education, 18, 665-673. https://doi.org /10.1016/S0742-051X(02)00026-4

Chong, W. L., \& Norsimah, M. A. (2007). Chinese private education system in Malaysia: A counter-reaction to language planning. Proceedings of SoLLs IntecUniversiti Kebangssan Malaysia, 2007, 85-94.

Etikan, I., Musa, S. A., \& Alkassim, R. S. (2016). Comparison of convenience sampling and purposive sampling. American Journal of Theoretical and Applied Statitstics, 5(1), 1-4. https://doi.org/10.11648/j.ajtas.20160501.11

Evans, L. (1997). Understanding teacher morale and job satisfaction. Teaching and Teacher Education, 13, 831-845. https://doi.org/10.1016/S0742-051X(97)00027-9

Farah Shazlin Johari, Muhammad Ridzuan Ruslani, Nor Maslia Rasli Samudin, Nurhafizah Mohd Zolkapli, \& Siti Norashikin Basirun. (2018). Understanding teachers' job satisfaction through work-life balance policies. Journal of Academia UiTM Negeri Sembilan, 6(1), 112-119.

Fatima, F., \& Ali, S. (2016). The impact of teachers' financial compensation on their job satisfaction at higher secondary level. Journal of Socialomics, 5(3), 1-11. https:// doi.org/10.41 72/2167-0358.1000164

Fernet, C., Trepanier, S-G., Austin, S., \& Levesque-Cote, J. (2016). Committed, inspiring, and healthy teachers: How do school environment and motivational factors facilitate optimal functioning at career start? Teaching and Teacher Education, 59(2016), 481-491.

Gil-Flores, J. (2017). The role of personal characteristics and school characteristics in explaining teacher job satisfaction. Revista de Psicodidáctica, 22(1), 16-22.

Gill, S. K. (2013). Language policy challenges in multi-ethnic Malaysia (Vol. 8). Dordrecht, Netherlands: Springer Science \& Business Media.

Hoque, K. E., Ahmad Zabidi Abdul Razak, \& Zohora, M. F. (2012). Excellent teachers and their job satisfactions: An analysis at Malaysia's standpoint. International Journal of Academic Research in Progressive Education and Development, 1(4), $1-16$.

Ingersoll, R. (2001). Teacher turnover and teacher shortages: An organizational analysis. Retrieved from https://repository.upenn.edu/gse_pubs/94

Kadtong, M. L., Unos, M. A., Antok, T. D., \& Midzid, M. A. E. (2017). Teaching performance and job satisfaction among teachers at Region XII. Proceedings Journal of Education, Psychology and Social Science Research,4(1), 113-122. 
Koustelios, A. D. (2001). Personal characteristics and job satisfaction of Greek teachers. International Journal of Educational Management, 15(7), 354-358.

Lam, B-H., \& Yan, H-F. (2011). Beginning teachers' job satisfaction: The impact of school-based factors. Teacher Development, 15(3), 333-348.

Lee，Z. P. (2007). 独中教育教学研究-独中师资队伍建设: 校园经济视角, 马来 西亚华文教育 [Investigation on teaching methods in Chinese Independent Schools: From the academic staff and economy perspective, Chinese Education in Malaysia]. Retrieved 1 April 2012, from http://www.djz.edu.my/resource/ index.php?option=com_content\&view $=$ article\&id=857:2009-08-11-03-4304\&catid=78:20077\&Itemid=2

Lee, G. H. Y., \& Leeves, G. (2015). A case study of a Chinese independent school. Policy Ideas No. 23. Retrieved from http://www.ideas.org.my/policy-paper-no-23-casestudy-chinese-independent-school/

Low, M. J. (2015). Chinese private schools as a viable route to secondary education in Malaysia: A case study. Malaysian Journal of Chinese Studies, 4(2), 45-59.

Mafuzah Mohamad, \& Juraifa Jais. (2016). Emotional intelligence and job performance: A study among Malaysian teachers. Procedia Economics and Finance, 35, 674-682.

Maslow, A. H. (1943). A theory of human motivation. Psychological Review, 50(4), 370396. https://doi.org/10.1037/h0054346

McCarthy, C. J., Lineback, S., Fitchett, P. G., Lambert, R. G., Eyal, M., \& Boyle, L. H. (2017). The role of culture and other contextual factors in educator stress. In S. E. McIntyre, D. J. Francis, \& T. McIntyre (Eds.), Educator Stress (pp. 157-177). Cham: Springer. https://doi.org/10.1007/978-3-319-53053-6_7

Ministry of Education. (2012). Preliminary report Malaysia education blueprint 20132025. Kuala Lumpur, Malaysia: Author.

Muhammad Madi Abdullah, Uli, J., \& Parasuraman, B. (2009). Job satisfaction among secondary school teachers. Jurnal Kemanusiaan, 13, 12-18.

Osborne, J. W., \& Costello, A. B. (2009). Best practices in exploratory factor analysis: Four recommendations for getting the most from your analysis. Pan-Pacific Management Review, 12(2), 131-146.

Sargent, T., \& Hannum, E. (2005). Keeping teachers happy: Job satisfaction among primary school teachers in Rural Northwest China. Comparative Education Review, 49(2), 173-204. https://doi.org/10.1086/503582. Retrieved from http:// repository.upenn.edu/gansu_papers/1

Santhapparaj, A. S., \& Syed, S. A. (2005). Job satisfaction among academic staff in private universities in Malaysia. Journal of Social Sciences, 1(2), 72-76.

Sharma, R. D., \& Jyoti, J. (2006). Job satisfaction among school teachers. IIMB Management Review, 18(4), 349-363.

Siah, P. C., Ong, S. B. C., Tan, S. M., Sim, C. P., \& Thoo, R. Y. X. (2018). Factors affecting school choice: What do Malaysian Chinese parents want? Journal of School Choice, 12(1), 34-51. https://doi.org/10.1080/15582159.2017.1408001

Skaalvik, E. M., \& Skaalvik, S. (2009). Does school context matter? Relations with teacher burnout and job satisfaction. Teaching and Teacher Education, 25, 518-524. https://doi.org/10.1016/j.tate.2008.12.006 
Spector, P. E. (1985). Measurement of human service staff satisfaction: Development of the job satisfaction survey. American Journal of Community Psychology, 13, 693-713.

Spector, P. E. (1997). Job satisfaction: Application, assessment, causes, and consequences. California: SAGE Publications, Inc.

Tafida, S. K., Che Kum Clement, \& Md Abu Raihan. (2015). Determining the causes for the exodus of technical teachers from teaching in technical and vocational institutions to other jobs in Katsina State, Nigeria. International Journal of Vocational and Technical Education, 7, 14-19.

United Chinese School Committees' Association of Malaysia. (2019). Retrieved from https://www.dongzong.my/v3/en/

Zainudin Awang, Junaidah Hanim Ahmad, \& Nazmi Mohamed Zain. (2010). Modelling job satisfaction and work commitment among lecturers: A case of UiTM Kelantan. Paper presented at the Proceedings of the Regional Conference on Statistical Sciences 2010 (RCSS'10), Universiti Teknologi MARA, pp. 241-255.

Zarisfizadeh, S. (2012). Job satisfaction factors among English language teachers In Malaysia. International Journal of Applied Linguistics \& English Literature, $1(4), 30-36$.

Zigarreli, M. A. (1996). An empirical test of conclusions from effective school research. The Journal of Educational Research, 90(2), 103-109. 